4.4. Trzeba rozwinąc teologię $z$ martwychwstania. $\mathrm{Z}$ wielu prac przytoczymy tylko ważne monografie F. X. D u r w ella, D. M. Stan le y a czy ostatnią B. Riga ux ${ }^{32}$. Chodzi tu o aspekt misteryjny, eschatologiczny, wspólnotowy i egzystencjalny zmartwychwstania Chrystusa dla życia chrześcijan.

4.5. I wreszcie proble m języka. W. Pannenberg nazywa pojęcie zmartwychwstania metaforą absolutną. Problem języka, w jakim wyrażać się będzie dzisiaj prawdę o zmartwychwstaniu, jest problemem hermeneutycznym. Słusznie pisze J. Delor$\mathrm{me}^{33}$, że kwestie hermeneutyczne dominują nad zagadnieniem zmartwychwstania Jezusa. Nie chodzi już o krytykę literacką czy historyczną. Istnieje przed nami problem sensu tekstów, naszych zdolności zrozumienia tego sensu $\mathrm{w}$ naszym języku, tak przecież różnym od tego, w jakim został opisany fakt zmartywchwstania.

Wielką usługę mogą nam oddać a n a li z y struktura lis ty c zn e prowadzone nad tekstami mówiącym o zmartwychwstaniu Jezusa ${ }^{34}$. Ważne jest to, by nie stracić proporcji badawczych na rzecz jednostronnych metod, niewątpliwie interesujących, ale niezdolnych do samodzielnego oddania tej tak bogatej rzeczywistości zmartwychwstania Jezusa ${ }^{3 \bar{n}}$.

Kraków

KS. JERZY CHMIEL

\title{
Ks. Miloslaw Kolodziejczyk
}

\section{TEOLOGICZNE ZALOŻENIA PRAKTYKI ODPUSTOWEJ}

Jedna $z$ form kościelnej praktyki pokutnej, uformowana ostatecznie w XI w., otrzymała (od XIII w.) techniczną nazwę indulgentia, a w języku polskim przyjęła się nazwa odpust. Oficjalnie przyjęta w Kościele definicja rzeczowa mówi, że ,odpust jest to darowanie wobec Boga kary doczesnej za grzechy, zgładzone

32 F. X. Durwe11, La Résurrection de Jésus. Mystère de salut, Lc Puy Lyon Paris ${ }^{31961 . ~-~ D . ~ M . ~ S ~ t ~ a ~ n ~ l e ~ y, ~ C h r i s t ' s ~ R e s u r r e c t i o n ~ i n ~ P a u l i n e ~}$ Soteriology (Anal Bibl 13), Rome 1961. Zob. dyskusję na łamach ,Theologische Quartalschrift" Tübingen, 153 (1973) nr 3: Die Entstehung des Auferstehungsglaubens. - Zob. także E. Pouss et, Croire en Résurrection, w: NRT 106 (1974).

${ }_{33} \mathrm{~W}$ : Le langage de la foi dans l'Ecriture et dans le monde actuel (Lect div 72), Paris 1972, 101-182.

3ï Zob. L. Dupont, Ch. Lash, G. Levesque, Recherche sur la structure de Jean 20, w: Biblica 54 (1973) 482-498.

35 Zob. studia poświęcone zmartwychwstaniu w: U. Gerber i E. G üttg e m a n n (red.), Linguistische Theologie, Bonn 1972. 
już co do winy. Dostępuje go chrześcijanin odpowiednio usposobiony i pod pewnymi, określonymi warunkami za pośrednictwem Kościoła, który jako szafarz owoców odkupienia rozdaje i prawomocnie przydziela zadośćuczynienia ze skarbca zasług Chrystusa i Swiętych" 1

W powyższej definicji zawiera się cała istotna nauka katolicka o odpustach i zarazem podstawowe założenia teologiczne praktyki odpustowej. Założenia te można sprowadzić do zagadnień: odpuszczenie doczesnej kary grzechowej, duchowego skarbca zasług, władzy Kościoła dysponowania nim i warunków oraz dyspozycji koniecznych do uzyskania odpustu.

\section{DOCZESNA KARA GRZECHOWA}

Odpust nie jest zgładzeniem grzechów jako takich, ale odpuszczeniem jedynie doczesnej kary grzechowej. Chodzi tu o kary wobec Boga, a nie o kary kanoniczne nakładane przez Kościół, co było stosowane w pokutnej praktyce pierwszych wieków.

Teologia katolicka rozróżnia w skutkach sprawianych przez grzech obrazę wyrządzoną Bogu przez odwrócenie się od Niego i zerwanis z Nim przyjaźni, co jest określane jako wina grzechowa (reatus culpae). Za winę grzechu ciężkiego czeka kara wiecznego odrzucenia (reatus poenae aeternae). Ponadto każdy grzech powoduje we wnẹtrzu człowieka, powiększając grzeszne skłonności, oraz w jego otoczeniu pewien nieporządek, który pociąga za sobą, wiążące wobec Boga, kary doczesne (reatus poenae temporalis). Nazywa się je doczesnymi, ponieważ mają wymiar skończony i człowiek może uczynić im zadość w czasie doczesnego życia ziemskiego.

Rozróżnienie powyższe przypomina konstytucja apostolska pap. Pa w $\nmid$ a VI Indulgentiarum doctrina z 1967 r., kiedy wyjaśnia, że do pełnego odpuszczenia grzechu i całkowitej jego naprawy ,konieczne jest nie tylko odnowienie przyjaźni z Bogiem przez szczere nawrócenịe duchowe i odpokutowanie obrazy wyrządzonej Jego mądrości i dobroci, lecz także całkowite przywrócenie wszystkich dóbr, pomniejszonych przez grzech, tak osobistych jak społecznych i tych, które odnoszą się do samego porządku wszechrzeczy" (ID, n. 3).

Praktyka udzielania odpustów zakłada nie tylko rozróżnienie między winą grzechową i karą wiẹczną a karą doczesną, ale także rzeczową różnicę między odpuszczeniem wobec Boga doczesnej kary grzechowej, która może pozostawać do odpokutowania po zgładzeniu tamtych pierwszych. To znaczy, że człowiek po dostąpieniu usprawiedliwienia czyli po odpuszczeniu winy

1 Paulus VI, Constitutio apostolica Indulgentiarum doctrina, $\mathrm{z} 1$ stycznia. 1967. AAS 59 (1967), 5-24. Polskie thumaczenie: Ruch Bibl. i Lit. 20 (1537) 1-13. ID, n. (- Indulgentiarum doctrina, liczba oznacza numer w jej tekście). 
grzechowej i kary wiecznej może mieć jeszcze do odpokutowania kary doczesne, za które musi zadośćuczynić - jak to zdefiniował Sobór Trydencki (DS 1580; Br. F. VII, 106) ${ }^{2}$ - w czasie życia ziemskiego lub przyszłego $\mathrm{w}$ pośmiertnym oczyszczeniu czyśćcowym.

Sobór Trydencki określając powyższą prawdę na innym miejscu (DS 1543; Br. F. VII, 73) odwołuje się do przykładów opisanych w Piśmie św., że Pan Bóg odpuszczając grzech nie zawsze odpuszcza mu całą karę, ponieważ za grzechy już odpuszczone zsyła jeszcze kary. Odpuścił Pan Bóg Izraelitom grzech niewierności a mimo to spotyka ich jeszcze kara. I odpowiedział Jahwe: „Odpuszczam zgodnie $z$ twoim slowem. Lecz... nie zobacza kraju, który obiecałem poil przysięga ich ojcom. Żaden $z$ tych, którzy Mna wzgardzili, nie zobaczy go (Lb 14, 20-23). Ta sama kara spotyka Mojżesza i Aarona (por. Lb 20, 12). Podobnie było z Dawidem. Dawid rzekł do Natana: „,Zgrzeszyłem wobec Jahwe”. Natan odrzekł Dawidowi: „Jahwe odpuszcza ci też twój grzech - nie umrzesz. Lecz dlatego, że przez ten czyn odważyłeś się wzgardzić Jahwe, syn, który ci się urodzi, napewno umrze (2 Sm 12, 13-14).

Powyższe przykłady faktycznie wskazują, że możliwe jest odpuszczenie winy grzechowej i kary wiecznej bez równoczesnego odpuszczenia pewnych przynajmniej kar, które trzeba znieść nawet po pojednaniu się już z Panem Bogiem.

Omawiane rozróżnienie między odpuszczeniem winy i kary wiecznej a odpuszczeniem kary doczesnej ma swoje potwierdzenie w nauce o czyśćcowym czyli pośmiertnym oczyszczaniu się dusz ludzi sprawiedliwych z pozostałych im jeszcze do odpokutowania - mimo usprawiedliwienia - doczesnych kar grzechowych. „Jeśli prawdziwie pokutujący - wyjaśnia Sobór Florencki w dekrecie dla Greków - zakończyli życie w miłości Boga jeszcze przed godnym zadośćuczynieniem czynami pokutnymi za popełnione grzechy i zaniedbania, wówcza dusze ich zostaną po śmierci oczyszczone karami czyśćcowymi (DS 1304; Br. F. VIII, 112; Por. Sob. Tryd. DS 1820; Br. F. VIII, 117).

Nauk katolicka i teologia przyjmują możliwość pozostawania po zgładzeniu winy i kary wiecznej - doczesnych kar grzechowych. Nie określają jednak dokładniej ich n a tury, co ma doniosłe znaczenie dla zrozumienia natury odpustu.

Papież $\mathrm{Paw}$ e 1 VI stwierdza tylko ogólnie, że kary te „muszą być poniesione albo na tym świecie przez cierpienia, nędze i utrapienia tego życia, a zwłaszcza przez śmierć, albo też w przyszłym życiu przez ogień i męki czyli kary czyśćcowe" (ID, n. 2).

2 Użyte skróty odsyłają do zbiorów dokumentów Kościoła. DS H. Denzing er, A. S chönmetzer, Enchiridion Symboloroum..., wydanic 32, Herder 1963; Br. F. - J. M. S z y m us iak i S. Głowa, Breviarium Fidei..., Poznań. 
Współcześni teologowi e ${ }^{3}$ podkreślają, że doczesnym karom grzechowym nie można przypisywać charakteru tylko windykatywnego, czysto zewnętrznego w stosunku do człowieka. Muszą mieć one także leczniczy charakter, ponieważ znoszenie ich pomaga do wewnętrznego oczyszczania i uwalnia od następstw grzechowych. Czyli muszą być zapodmiotowane we wnętrzu człowieka. Stąd do ich odpuszczenia konieczna jest odpowiednia wewnętrzna przemiana, wewnętrzny proces oczyszczający. Darowania kar doczesnych drogą odpustu nie można by więc pojmować na wzór amnestii, moca której wszystkim, zarówno tym, którzy się poprawili, jak i tym, którzy nadal pozostali niepoprawnymi, odpuszcza się kary, ale nałożone z zewnątrz przez władze karne. Do otrzymania darowania kar doczesnych czyli do zyskania odpustu konieczne jest odpowiednie usposobienie wewnętrzne, o czym będzie jeszcze mowa w końcowej części.

Z woli udzielającego odpust może zmierzać do złagodzenia całej kary doczesnej, jaką człowiek dostępujący odpustu ma jeszcze do odpokutowania za grzechy odpuszczone już co do winy i wtedy mówi się o odpuście z u pełnym. Odpust c zęściowy uwalnia natomiast tylko od części dłużnej kary doczesnej. Wielkość odpustu częściowego nie jest już określana przy pomocy niezrozumiałych, a pochodzących ze wczesno-średniowiecznej pokuty taryfowej wielkości czasowych (dni czy lat) ale przy pomocy wartości zadośćuczynnej, jaką posiada samo z siebie spełnienie czynności obdarzonej przez Kościól częściowym odpustem. „Wierny, który przynajmniej z sercem skruszonym wypełnia czynność obdarzoną odpustem częściowym - postanowił $\mathrm{P}$ a w e 1 VI uzyskuje za pośrednictwem Kościoła odpuszczenie takiej kary doczesnej, jakiej odpuszczenia dostępuje sam już na mocy swej czynności" (ID, norma 5) ${ }^{4}$.

\section{DUCHOWY SKARBIEC KOŚCIOEA}

Doktrynę o duchowym skarbcu Kościoła (thesaurus Ecclesiae) wypracowała teologia średniowieczna, a do nauczania Kościoła wprowadził ją papież Klemens VI w jubileuszowej bulli Unigenitus Dei Filius z 1347 r. (DS 1025n; Br. F. VII, 409n) dla uzasadnienia powstałej i już rozpowszechnionej praktyki odpustowej ${ }^{5}$.

Skarbiec (czy skarb) Kościoła to określenie obrazowe, które nie oddaje adekwatnie oznaczanej rzeczywistości i dlatego może prowadzić do błędnego rozumienia omawianej prawdy. Dlatego konstytucja

3 Por. O. Semmelroth, Zur Theologie des Ablasses, w: Nachkonziliare Dokumentation, Trier 1967, Bd II, s. $55 \mathrm{nn}$; K. R a hn er, Sündenstrafen, w: LTK, Freiburg2 1964, t. IX, 1185-1187.

${ }_{4}$ Por. mój artykuł, Nowa miara odpustu częściowego, w: Ruch Bibl. i Lit. 21 (1968) $147-159$.

5 Por. K. Rahner, Kirchenschatz, w: LTK, t. IV, 257. Tam dalsza bibliografia na poruszany temat. 
Indulgentiarum doctrina, zanim przystąpi do pozytywnego wykładu, wyjaśnia naprzód, czym ten skarbiec nie jest, jak nie należy go pojmować. „Nie jest on (tzn. duchowy skarbiec Kościoła) zbiorem dóbr, zgromadzonych bogactw" (ID, n. 5). Nauka katolicka o d c in a się więc wyraźnie od materialno-rzeczowego pojmowania duchowego skarbca Kościoła, a konsekwentnie i udzielanego odpustu, jak to się zdarzało w historii praktyki odpustowej.

Pozytywne przedstawienie nauki o duchowym skarbcu Kościoła oraz jego skuteczności opiera się na tajemnicy świętych obcowania, wyrażającej żywe i dogłębne zjednoczenie i ścisłą wspólnotę wszystkich wiernych należących do mistycznego Ciała Chrystusa. Na mocy więzi łączących wszystkich wiernych, ,grzech jednego szkodzi także innym, podobnie jak świętość jednego wyjaśnia konstytucja - przynosi dobrodziejstwo innym" (ID, n. 4). Dopiero na tle nadprzyrodzonej łączności całego mistycznego Ciała Chrystusa ukazany zostaje duchowy skarbiec Kościoła.

Skarbcem tym jest, ,s a Chrystus Odkupiciel, w którym są i działają zadośćuczynienia i zasługi płynące z Jego odkupienia" (ID, n. 5). Dokonane w historii dzieło odkupienia Chrystusowego, przez Jego zmartwychwstanie, stało się rzeczywistością ponadhistoryczną, wiecznie obecną przed Bogiem i w ten sposób umożliwiającą ludziom wszystkich czasów korzystanie $\mathrm{z}$ jego owoców, aby się uwalniać od zgubnych skutków grzechowych i dochodzić do nadprzyrodzonego zjednoczenia z Bogiem.

Obok Chrystusa Odkupiciela, ale w ścisłej łączności z Nim, duchowym skarbcem Kościoła są Święci na czele ż Najświętszą Dziewicą. W czasie ziemskiego życia chętnie nieśli swój krzyż idąc za cierpiącym Chrystusem i zadośćczynili za swoje i swoich bliźnich grzechy, pomagając swoim współbraciom na drodze zbawienia. „Poza tym do tego skarbu - wyjaśnia papież P aw e $\nmid V$ - należy też wartość naprawdę ogromna, niewymierna i zawsze świeża, jaką mają przed Bogiem modlitwy i dobre uczynki Najświętszej Maryi Panny i wszystkich Świętych, którzy idąc śladami Chrystusa dzięki jeg̉o łasce, uświęcili samych siebie i spełnili posłannictwo otrzymane od Ojca. W ten sposób pracując nad wlasnym zbawieniem, przyczynili się również do zbawienia swych braci w jedności mistycznego Ciała" (ID, n. 5).

Z powyższego wyjaśnienia wynika, że wstawienicza działalność Swiętych $\dot{w}$ niebie polega na tym, iż to, co wnieśli oni $w$ czasie ziemskiego życia do zbawczego dzieła Chrystusa, zachowuje wciąz swą wartość przed Bogiem i przez to samo oddziaływuje na zbawienie ludzi ${ }^{6}$. Swięci, przyjęci do niebieskiej Ojczyzny, znajdują się „,blisko

6 Por. O. Semmelroth, art. cyt., s. 61. 
przy Panu (por. 2Kor 5,3) - jak wyjaśnia Konstytucja dogmatyczna o Kościele - przez Niego, z Nim i w Nim nieustannie wstawiają się za nas u Ojca, ofiarując Mu zasługi, które przez jedynego Pośrednika. między Bogiem i ludźmi, Jezusa Chrystusa (por. 1 Tym 2,5), zdobyli na ziemi, służąc Panu we wszystkim i w ciele swoim dopełniając tego, czego nie dostaje cierpieniom Chrystusowym, za ciało Jego, którym jest Kościół” (KK, n. 49).

Duchowym skarbcem, do którego odwołuje się i z którego korzysta Kościól przy udzielaniu odpustów, to sam Jezus Chrystus, jedyny Pośrednik i Odkupiciel całej ludzkości oraz Święci (na czele z Najświętszą Dziewicą), za którymi poszły ich czyny zbawcze (por. Ap 14, 13) przed oblicze Boga i teraz umożliwiają Kościołowi odwoływanie się do nich, kiedy pomaga swoim wiernym w pokutnym oczyszczaniu. się z pozostałych im jeszcze do odpokutowania doczesnych kar grzechowych.

W przedstawianiu nauki o duchowym skarbcu Kościoła należy więs za wszelką cenę unikać pojmowania i przedstawiania go jako pewnego rodzaju zasobu czy zapasu dóbr materialnych. Duchowy skarbiee Kościoła, jak wynika z powyższych wyjaśnień, ma charakter wyraźnie osobowy. Stanowi go wprawdzie nadobfite zadośćuczynienie, ale ściśle powiązane z Osobą Odkupiciela i ze Świętymi. Skarbca zasług i zadośćuczynień nie można oddzielać od Chrystusa-Odkupiciela i Jego naśladowców - Swiętych. Zadośćuczynienie nie jest bowiem wielkością istniejącą samą $\mathrm{w}$ sobie, ale jest to wielkość czy wartość, jaką posiadają zbawcze czyny Jezusa Chrystusa i czyny Świętych, pozostających w ścisłej łączności ze Swoim Mistrzem.

\section{WEADZA KOŚCIOEA}

Swoją władzę udzielania odpustów, czyli prawo dysponowanir duchowym skarbcem zasług i zadośćuczynień Chrystusa Pana i Świętych, wyprowadza Kościół z przekazanej mu przez Chrystusa władzy związywania i rozwiązywania, zwanej władzą kluczy. Przekazał ją Pan Jezus w słowach skierowanych do św. Piotra: I tobie dam klucze królestwa niebieskiego; cokolwiek zwiażesz na ziemi, będzie zwiazane $i w$ niebie, a co rozwiazesz na ziemi, będzie rozwiazane $w$ niebie (Mt 16, 19. Por. analogiczne słowa skierowane do wszystkich razem Apostołów - Mit 18, 18).

Skoro w powyższych słowach przekazane zostało Kościołowi uprawnienie i zarazem zadanie uwalniania ludzi od wszystkich skutków grzechowych (zarówno od winy jak i od kary), a w ten sposób usuwania przeszkód, jakie ludzie napotykają na drodze do królestwa niebieskiego, to w tej władzy musi się takż zawierać i w $ł a d z a$ udzielania odpustów, tzn. prawo dysponowania ze wspólnego skarbca zadośćuczynień na korzyść swoich wiernych, celem odpuszczenia im doczesnych kar grzechowych. Praktykę udzie- 
lania odpustów wprowadziło bowiem ,przeświadczenie istniejące w Kościele o tym, że Pasterze Pańskiej owczarni - jak wyjaśnia Paweł VI - mogą uwolnić poszczególnych wiernych od pozosta.łości po grzechach przez przydział zasług Chrystusa i Swiętych" (ID, n. 7).

Co jest wspólnym dobrem społeczności, jak wspomniany duchowy skarbiec zasług i zadośćuczynień, to może być przydzielane poszczególnym członkom spoleczności według woli i uznania kierującego daną społecznością. Stąd przepis prawa kościelnego, że „oprócz Papieża, któremu powierzone zostało przez Chrýstusa Pana szafowanie całym skarbcem duchowym Kościoła, tylko ci mogą władzą zwyczajną rozdzielać odpusty, którym zostało to udzielone wyraźnie przez prawo" ". Kongregacja dla Nauczania Wiary czuwa - z ramienia papieża - nad czystością nauki o odpustach. Zaś uprawnienia w zakresie udzielania i korzystania z odpustów powierzone są wyłącznie. Penitencjarii Apostolskiej ${ }^{8}$.

Odpuszczenia doczesnej kary grzechowej wobec Boga, mocą udzielonego odpustu, dokonuje Kościół na drodze p o z a s a k r me n t a 1$n \in j$. To nie jest odpuszczenie tego rodzaju, jakiego Kościół udziela moca sakramentu pokuty, kiedy rozgrzesza od winy i kary wiecznej oraz częściowo przynajmniej - zależnie od dyspozycji penitenta od doczesnych kar grzechowych.

Gdy chodzi o odpusty udzielane przez Kościól za dusze z ma r$\nmid \mathrm{ych}$, to od wprowadzenia ich do praktyki (przez papieża Systusa IV, bullą Salvator noster z 3 sierpnia 1476 r. - DS 1398) zostało okreś-lone, że udziela się ich na sposób prośby, czyli wstawiennictwa (per modum suffragii). To znaczy, że Kcściół - nie mając już władzy nad duszami zmarłych - ofiarowuje Bogu zadośćuczynienie ze wspólnego skarbca i prosi Boga, aby raczył je policzyć na korzyść danej duszy, jeśli przebywa w stanie pośmiertnego oczyszczenia. Faktyczne jednak przyjęcie tego zadośćuczynienia i zaliczenie go na korzyść danej duszy, zależy całkowicie od woli i upodobania Bożego. Dlatego nie można powiedzieć nic pewnego na temat skuteczności odpustu za zmarłych ${ }^{9}$.

Trudniej jest natomiast określić dokładniej sposób udzielania i skuteczności odpustu przez Kościół dla ludzi ż y ją c y c h.

Niektórzy teologowie, jak np. R. B ella r min ${ }^{10}$ czy F. Suarez ${ }^{11}$, głoszą pogląd, że ludziom żyjącym udziela Kościół odpustu na

7 Enchiridion indulgentiarum. Normae et conessiones, Libreria editrice Vaticana 1968, Norma 8. Por. KPK kan. 912.

8 Tamże, Norma $9 \mathrm{nn}$.

9 Borównaj orzeczenie Kongregacji Odpustów z dnia 28 lipca $1840 \mathrm{r}$. Decreta authentica Sacrae Congregationis Indulgentiarum, Ratisbonae, 1883, n. 283.

10 De indulgentiis, 1.1 , cp. 5-6.

11 De poenitentia, disp. 53 , sect. $3-4$. 
sposób rozgrzeszenia (per modum absolutionis). To znaczy, że Kościół - mocą władzy jurysdykcyjnej - bezpośrednio i w znaczeniu wlaściwym rozgrzeszałby danego wiernego od kary doczesnej (całkowicie czy częściowo), jaką ma jeszcze do odpokutowania i to wobec Boga. Przy odpuście nie chodzi bowiem - warto jeszcze przypomnieć - o kary pokutne wiążące tylko wobec Kościoła. Z kar kościelnych napewno Kościół może rozgrzeszać, skoro może je nakłədać. Ale tu chodzi o kary doczesne wiążące wobec Boga i o odpuszczanie ich na drodze pozasakramentalnej. Stąd trudności.

Inni teologowie, jak np. Sw. To $\mathrm{mas}^{12}$, sądzą, że przez udzielanie odpustu Kościół nie rozgrzesza bezpośrednio wiernego od doczesnych kar grzechowych wobec Boga, ale udziela mu ze wspólnego skarbca zadośćuczynienia, które wierny zyskujący odpust składa Bogu jako rekompensatę za odpuszczone $\mathrm{mu}$ - bezpośrednio przez Pana Boga - doczesne kary grzechowe. Czyli odpust dla żyjących byłby udzielany na sposób z a p l a ty (per modum solutionis).

W ostatnich dziesiątkach lat niektórzy teologowie, jak B. P o s c hman $n^{13}$ i kontynuujący jego poglądy w tym względzie $K$. $R$ a hne ${ }^{14}$ wystąpili $z$ teorią, że również i odpusty dla żyjących udzielane są na sposób oficjalnego wstawiennictwa, urzędowej prośby czyli modlitwy Kościoła (także per modum suffragii). Przeciw tej opinii wysuwana jest między innymi trudność ${ }^{15}$ uzgodnienia jej z nauka Kościoła, ponieważ i papież $\mathrm{Paw}$ a ł VI stwierdza, że „w odpuście bowiem Kościół, używając swej władzy szafarza z owoców odkupienia Chrystusa Pana, nie tylko się modli, lecz wiernym odpowiednio przysposobionym prawomocnie rozdziela (auctoritative dispensat) skarb zadośćuczynień" (ID, n. 8). Papież nie mówi jednak nigdzie, że odpusty dla żyjących udzielane są na sposób rozgrzeszenia. K. R ahner stara się wykazać, że tzw. now a teoria odpustu, głoszona także przez niego, nie jest sprzeczna z nauką papieża Pawła VI ${ }^{16}$.

Kościół jest więc świadomy i przekonany, że ma władzę udzielania odpustów, co zdefiniowal dogmatycznie na Soborze Trydenckim (por. DS 1835; Br. F. VII, 503), ale nadal poozstaje do wyjaśnienia bliższe określenie rodzaju władzy, mocą której udzielane są odpusty dla żyjących oraz sposób ich skuteczności.

12 Suppl., q. 25, a. 1, ad 2.

13 Der Ablass im Lichte der Bussgeschichte, Bonn 1948; Tenże, Busse und letzte Olung, w: Handbuch der Dogmengeschichte, t. IV, 3, s. 112-123.

14 Bemerkungen zur Theologie des Ablasses, w: Schriften zur Theologie, t. II (Einsiedeln 7 1964), 185-210.

15. R a si, Nuove idee sulla dottrina delle indulgenze, w: Osservatore Romano, 26. II. 1966 , n. 46 , s. 6 .

16 Por. K. Rahner, Zur heutigen kirchenamtlichen Ablasslehre, w: Catholica 21 (1967), 261-286. 


\section{WARUNKI ZYSKANIA ODPUSTU}

Pewne warunki, konieczne do zyskania odpustu, wynikają już z faktu, że odpusty może rozdziclać Kościół tylko tym, którzy n ależą do jego społeczności. Stąd zrozumiałe jest, że odpu. sty mogą zyskiwać tylko ochrzczeni, wolni od ekskomuniki, będący poddanymi udzielających odpustu.

Skuteczność odpustów zależy od wewnętrznej dyspozyc ji przyjmującego. Zgładzenie doczesnych kar grzechowych wymaga bowiem wewnętrznej przemiany oczyszczającej, ponieważ kary grzechowe nie są karami zewnętrznie dołączonymi do człowieka, ale jako skutki grzechu - zapodmiotowane są w jego wnętrzu, dopóki nie nastąpi całkowite oczyszczenie z pozostałości grzechowych. Darowanie kar doczesnych, jak w ogóle odpuszczenie grzechów, nie może się dokonać bez zerwania z grzechem, bez pokutnego usposobienia. Stąd wynika, że do uzyskania odpustu wymagane są dyspozycje, a mianowicie konieczne jest, aby wierny ,kochał Boga - jak wyjaśnił P a weł VI - brzydził się grzechem, pokładal ufność w zasługach Chrystusa Pana i wierzył niezachwianie, że wspólnota Świętych jest dla niego wielkim pożytkiem" (ID, n. 9).

Konieczne jest pojednanie się z Bogiem, czyli stan laski (przynajmniej przy końcu wypełniania przepisanych czynności). Do uzyskania odpustu z u pe $¥$ n e g o koniecznymi warunkami są zawsze spowiedź sakramentalna i Komunia św. - jako środki pojednania i łaczności z Bogiem. Na łączność z całą wspólnotą wierzących w Chrystusa ma wskazywać - obowiązkowa zawsze do.uzyskania odpustu zupełnego - modlitwa na intencję Ojca św.

Wymagane jest odpowiednie usposobienie pokutne. Do uzyskania odpustu częściowego mówią przepisy - jak wyżej zaznaczono - o wypełnieniu czynności obdarzonej odpustem częściowym przynajmniej z sercem skruszonym. Aby zyskać odpust zupełny, koniecznym warunkiem jest wolność od przywiązania do jakiegokolwiek grzechu nawet lekkiego. Dopóki wierny przywiązany jest choćby do lekkiego tylko grzechu, czyli aktualnie w nim trwa, dotąd nie ma wymaganej dyspozycji do odpuszczenia winy grzechowej, a tym samym nie wypełnia podstawowego warunku, ponieważ odpust gładzić może kary doczesne tylko za te grzechy, które zostały już odpuszczone co do winy. Jeśli wina grzechowa trwa, kara doczesna za ten grzech nie może zostać odpuszczona. Kiedy brakuje wspomnianej dyspozycji, wtedy odpust zupełny staje się faktycznie częściowym, tzn, gładzi doczesne kary za grzechy już odpuszczone co do winy (por. ID, norma 7).

Konieczne jest także wy pełnienie przepisanych czynności i to $z$ intencją (przynajmniej ogólną) zyskania odpustu Odpustem obdarza Kościół bowiem czyn ludzki, a nie miejsce czy 
rzecz świętą. Aby to podkreślić, ostatnia reforma dyscypliny odpustowej (ID, norma 12) zniosła rozróżnienie odpustów na osobowe, lokalne( przywiązane do miejsca) i rzeczowe (przywiązane do rzeczy poświęconej). Odpustem obdarza Kościół nawiedzenie kościoła np. katedralnego, a nie sam kościół, odmawianie różańca, a nie samą koronkę, itp.

Czynności, obdarzane przez Kościół odpustami, ze swej natury zmierzają także do tego, aby spełniający je wierny nabywał i powiększal w sobie postawę pokutną oraz wzrastał w miłości. Zatwierdzony i wydany w 1968 r. przez Penitencjarię Apostolską wykaz czynności obdarzonych odpustami ${ }^{17}$ wyraźnie wskazuje, że Kościół obdarza obecnie odpustami tylko szczególniejsze modlitwy oraz ważniejsze czyny pobożności, miłości i pokuty. Szczególniejsze, to znaczy takie, które uznał Kościół za odpowiednie, stosownie do warunków życia współczesnego człowieka, zarówno do wspomagania wiernych w zadośćuczynieniu za grzechy jak również i do pomnażania miłości Boga i bliźniego.

Częstochowa-Kraków

KS. MIEOSEAW KOEODZIEJCZYK

17 Por. mój artykuł, Dalsza reforma w dziedzinie odpustów, w: Ruch Bibl. i Lit. 22 (1969) 103-123. 